\title{
PREVALENCE OF PUTATIVE PERIODONTOPATHOGENS FROM PERIODONTAL PATIENTS AND HEALTHY SUBJECTS IN SÃO PAULO, SP, BRAZIL
}

\author{
Mario J. AVILA-CAMPOS(1) \& Gustavo VELÁSQUEZ-MELÉNDEZ(2)
}

\begin{abstract}
SUMMARY
A. actinomycetemcomitans, B. forsythus, $P$. gingivalis, $C$. rectus, E. corrodens, $P$. intermedia, F. nucleatum, and T. denticola were identified from subgingival plaque from 50 periodontal patients and 50 healthy subjects. PCR products from each species showed a specific band and could be used to identify periodontal organisms from clinical specimens. Identical negative or positive results between PCR and culture occurred in 66\% (A. actinomycetemcomitans) to 93\% (F. nucleatum) of the samples. PCR detection odds ratio values for $A$. actinomycetemcomitans, $B$. forsythus, $C$. rectus, E. corrodens, $P$. intermedia, and $T$. denticola were significantly associated with disease having a higher OR values for B. forsythus (2.97, 95\% CI 1.88 - 4.70). Cultures showed that $A$. actinomycetemcomitans, B. forsythus and P. intermedia were associated with periodontitis, however, P. gingivalis, C. rectus, E. corrodens and $F$. nucleatum were not significantly associated with the disease.
\end{abstract}

KEYWORDS: Periodontal pathogens; Periodontal disease; PCR.

\section{INTRODUCTION}

In oral microbiology it is essential to identify and characterize the various microorganisms involved in the different oral infections and such information will be useful for monitoring the disease progression ${ }^{6}$.

It is known that periodontal pockets can harbor more than 300 different bacterial species ${ }^{3,9}$. Organisms such as Actinobacillus actinomycetemcomitans, Fusobacterium nucleatum, Porphyromonas gingivalis, Prevotella intermedia or Eikenella corrodens have been considered to have a role in periodontal disease $e^{9,10}$. However, most of these organisms can also cause serious nonoral infections ${ }^{13}$.

Several studies have demonstrated a strong correlation between the presence of putative periodontal organisms and the destruction of periodontal tissues ${ }^{4,10}$.

Different methods of detecting phenotypic or genotypic variation have been used to characterize periodontal pathogens and differentiate them from commensal strains ${ }^{4}$.

Molecular methods are currently available for the identification and subtyping of bacterial strains such as A. actinomycetemcomitans and $P$. gingivalis, but they vary in efficiency and the amount of required labor ${ }^{5,7}$. Techniques used to identify putative anaerobic pathogens from destructive periodontal disease such as bacterial culture are somewhat cumbersome and expensive ${ }^{12}$.
Polymerase chain reaction (PCR) has been used for direct identification of periodontal pathogens in subgingival specimens ${ }^{2,11}$ and also for elucidating the role of specific bacteria in the periodontal disease because of the ability to accurately detect specific species in mixed populations. In Brazil, the polymerase chain reaction (PCR) is not routinely used for the identification of periodontal microorganisms.

Specific primers are powerful molecular tools for the identification, typing or detection of clinically important microorganisms. 16S rRNA gene amplification has been used for detection of microorganisms that can not be cultivated, but these methods have given cross reactions with related organisms ${ }^{11}$.

The goal of the present study was to detect putative periodontal microorganisms from clinical subgingival and gingival sulcus samples using conventional culture and 16S rRNA gene-based detection PCR methods.

\section{MATERIAL AND METHODS}

1. Patients and bacterial strains: Fifty periodontal patients (adult periodontitis) were selected from the School of Dentistry, at the University of São Paulo (São Paulo, SP, Brazil). All the patients showed clinical and radiographic evidence of alveolar loss confined to the molar and incisor teeth and periodontal pockets depth equal to or exceeding $5 \mathrm{~mm}$. Fifty healthy subjects without clinical signs of periodontal disease were also selected. Characteristics of both of the studied groups are shown in

(1) Department of Microbiology, Institute of Biomedical Science, University of São Paulo, São Paulo, SP, Brazil.

(2) Public Health Department, School of Nursing, Federal University of Minas Gerais, Belo Horizonte, MG, Brazil.

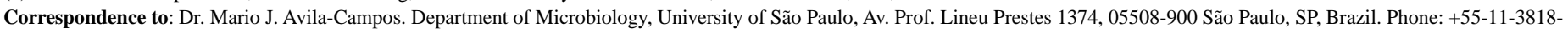
7344; Fax: +55-11-3818-7354; E-mail: mariojac@ icb.usp.br. 
Table 1. None of the periodontal patients or controls had received antibiotics for the least three months prior sample collection. Briefly, supragingival plaque was removed from teeth with cotton rolls. Subgingival samples were obtained from one periodontal site by three fine sterile paper points (Dentsply Ind. and Co. Ltd., RJ, Brazil), inserted to the depth of the pocket or sulcus and left in place for $60 \mathrm{~s}$. The paper points were transported in VMGA III medium ${ }^{8}$. Samples were subcultured within $2 \mathrm{~h}$ of collection. All samples were dispersed by vortexmixing at maximal setting for 60s and 10 -fold dilutions were prepared. Aliquots of $0.1 \mathrm{ml}$ of undiluted and $10^{-3}$ diluted sample solution were plated onto trypticase soy (Difco Laboratories)-horse serum-bacitracinvancomycin (TSBV) for A. actinomycetemcomitans, Omata \& Disraely agar for F. nucleatum, Brucella blood agar (Difco Laboratories) (5\% defibrinated sheep blood) supplemented with hemin $(0.0001 \mathrm{mg} / \mathrm{ml})$ and menadione $(0.0001 \mathrm{mg} / \mathrm{ml})$ for $B$. forsythus, C. rectus, $P$. gingivalis and $P$. intermedia, and Brucella blood agar with $0.1 \%$ clindamycin for $E$. corrodens. No growth medium was used for T. denticola. The TSBV medium and Omata \& Disraely agar were incubated for 3 days, and Brucella blood agar was incubated for seven days, at $37^{\circ} \mathrm{C}$ in atmosphere with $90 \% \mathrm{~N}_{2}+10 \% \mathrm{CO}_{2}$. Suspected colonies were selected from each sample and all the isolates were identified by colonial and cellular morphology (Gram) and by using conventional biochemical tests or ID 32-A kits (bioMérieux). Cultures were maintained on Brucella blood agar and stored at $-70^{\circ} \mathrm{C}$.

2. DNA extraction and analysis: From each clinical sample collected in VMGA III, $500 \mu \mathrm{l}$ of sample was mixed with $500 \mu \mathrm{l}$ of sterile Milli-Q water and washed twice at 12,000 rpm for 10 minutes. The pellet was resuspended in $500 \mu \mathrm{l}$ of Milli-Q water and boiled for 10 minutes. After centrifugation (14,000 rpm, 10 minutes) the supernatant was saved and transferred to a new tube and used as template.

3. PCR detection: Fifty clinical samples obtained from patients with adult periodontitis and 50 samples from healthy subjects were included in the PCR analysis. Primers (Table 2) were designed in accordance with ASHIMOTO et al. ${ }^{1}$ and were synthesized in the Biotechnology Core Facility Branch, Centers for Disease Control and Prevention (CDC, Atlanta, GA, USA). PCR amplification was performed in volumes of $25 \mu \mathrm{l}$ containing $1 \mathrm{X}$ PCR/Mg $\mathrm{Mg}^{++}$buffer (Boehring Mannheim, Indianapolis, IN, USA), $0.2 \mathrm{mM}$ each of dNTP (Pharmacia Biotech, Piscataway, NJ, USA), $0.5 \mathrm{U}$ Taq DNA polymerase (Boehringer Mannheim), $0.4 \mu \mathrm{M}$ of each primer pair and $10 \mathrm{ng}$ of template. Amplification was performed in a DNA Thermal Cycler (Perkin Elmer, GeneAmp PCR System 2400, Norwalk, CT, USA) programmed for $94{ }^{\circ} \mathrm{C}(5 \mathrm{~min})$, followed by 30 cycles at $94{ }^{\circ} \mathrm{C}$ for 30 seconds; annealing temperature adequate for each primer pair (Table 2) for 30 seconds; $72^{\circ} \mathrm{C}$ for 30 seconds, then $72{ }^{\circ} \mathrm{C}(5$ min) to allow the completion of DNA extension. A negative control without template DNA was included in each PCR run. Amplification products were compared by electrophoresis in $1 \%$ agarose gel in $1 \mathrm{X}$ TBE (1 M Tris, 0.9 M boric acid, 0.01 M EDTA, pH 8.4) buffer (Gibco BRL, Life Technologies, Ltd., Bethesda, MD, USA), stained with ethidium bromide $(0.5 \mathrm{mg} / \mathrm{ml})$, and photographed on a UV light transilluminator (Kodak Digital Science System 120). Molecular mass standard 1-Kb ladder (Gibco BRL) was included.

4. Statistical Analysis: All statistical analyses were performed using an Epi-info $^{\circledR} 6.04$ sofware (CDC/WHO). Standard methods to calculate descriptive statistics were used. The association between microbial detection by culture and PCR and periodontal disease was tested using a chi-square test ( $p$ values are two-sided and $\alpha=0.05$ ) and the odd ratios were calculated (OR, 95\% confidence interval). Cross tabulation to determine the matching results between culture and PCR for organisms detection using healthy subjects and periodontal patients $(n=100)$ was used.

\section{RESULTS}

Bacterial prevalence by PCR. Primer pairs were evaluated for identification of different putative periodontopathogens. Amplified products using bacterial DNA were compared and all primer pairs produced specific amplicons of predicted sizes (Fig. 1). Bacterial detection by PCR in the healthy and periodontitis subjects was $70 \%$ and $90 \%$ for A. actinomycetemcomitans, $92 \%$ and $96 \%$ for $F$. nucleatum, $66 \%$ and $78 \%$ for $P$. gingivalis and, $64 \%$ and $84 \%$ for $P$. intermedia (Table 3). When conventional culture was used for microbial detection from healthy subjects and patients we observed the following isolation rates: $48 \%$ and $80 \%$ for $A$. actinomycetemcomitans, $60 \%$ and $70 \%$ for $P$. gingivalis, $64 \%$ and $64 \%$ for E. corrodens, $84 \%$ and $90 \%$ for $F$. nucleatum, $50 \%$ and $74 \%$ for $P$. intermedia, $46 \%$ and $60 \%$ for C. rectus, $10 \%$ and $40 \%$ for B. forsythus. In addition the odds ratios (OR, 95\% confidence interval-CI) for periodontal patients compared to control is also given in Table 3. Organisms detected by PCR: $A$. actinomycetemcomitans, B. forsythus, C. rectus, E. corrodens, $P$. intermedia, and $T$. denticola were significantly associated with periodontal disease with $B$. forsythus having the highest OR $(2.97,95 \%$ CI $1.88-4.70)$. Bacterial isolation by culture detection showed that $A$. actinomycetemcomitans, $B$. forsythus and $P$. intermedia, were associated with periodontal disease, but, $P$. gingivalis, $C$. rectus, $E$. corrodens and F. nucleatum were not significantly associated with the disease.

Table 1

Characteristics of periodontal patients and healthy subjects analyzed

\begin{tabular}{|c|c|c|c|c|}
\hline & \multicolumn{2}{|c|}{ Periodontal patients $(n=50)$} & \multicolumn{2}{|c|}{ Healthy subject $(n=50)$} \\
\hline & Average $(\%)$ & Range & Average $(\%)$ & Range \\
\hline Age (years) & 45.5 & $18-65$ & 32.3 & $18-51$ \\
\hline \multicolumn{5}{|l|}{ Race: } \\
\hline White & 40 & - & 40 & - \\
\hline Black & 9 & - & 10 & - \\
\hline Oriental & 1 & - & - & - \\
\hline Periodontal pocket (mm) & 8.4 & $6-13$ & - & - \\
\hline
\end{tabular}




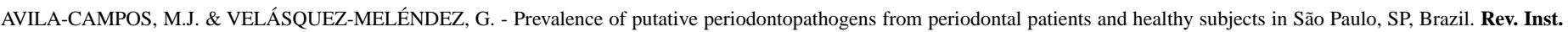
Med. trop. S. Paulo, 44(1):1-5, 2002.

Table 2

Nomenclature, composition and annealing temperature of the species-specific primer pairs for PCR

\begin{tabular}{|c|c|c|c|}
\hline Primers & $\begin{array}{l}\text { Oligonucleotide } \\
\text { sequence } 5^{\prime} \rightarrow 3^{\prime}\end{array}$ & $\begin{array}{l}\text { PCR annealing } \\
\text { temperature }\left({ }^{\circ} \mathrm{C}\right)\end{array}$ & $\begin{array}{l}\text { Amplicon } \\
\text { length }(\mathrm{Kb})\end{array}$ \\
\hline \multicolumn{4}{|c|}{ A. actinomycetemcomitans } \\
\hline & \multicolumn{3}{|l|}{ GCT AAT ACC GCG TAG AGT CGG } \\
\hline & ATT TCA CAC CTC ACT TAA AGG T & 50 & 0.5 \\
\hline \multicolumn{4}{|c|}{ B. forsythus } \\
\hline & \multicolumn{3}{|l|}{ GCG TAT GTA ACC TGC CCG CA } \\
\hline & TGC TTC AGT GTC AGT TAT ACC T & 60 & 0.6 \\
\hline \multicolumn{4}{|c|}{ (2)- } \\
\hline & \multicolumn{3}{|l|}{ TTT CGG AGC GTA AAC TCC TTT TC } \\
\hline & TTT CTG CAA GCA GAC ACT CTT & 50 & 0.6 \\
\hline \multicolumn{4}{|c|}{ 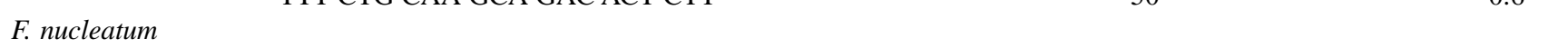 } \\
\hline & \multicolumn{3}{|l|}{ ATT GTG GCT AAA AAT TAT AGT T } \\
\hline & ACC CTC ACT TTG AGG ATT ATA G & 40 & 1.0 \\
\hline \multicolumn{4}{|c|}{ E. corrodens } \\
\hline & \multicolumn{3}{|l|}{ CTA ATA CCG CAT ACG TCC TAA G } \\
\hline & CTA CTA AGC AAT CAA GTT GCC C & 45 & 0.7 \\
\hline \multicolumn{4}{|c|}{ P. gingivalis } \\
\hline & \multicolumn{3}{|l|}{ AGG CAG CTT GCC ATA CTG CG } \\
\hline & ACT GTT AGC AAC TAC CGA TGT & 60 & 0.4 \\
\hline \multicolumn{4}{|c|}{ P. intermedia } \\
\hline & \multicolumn{3}{|l|}{ TTT GTT GGG GAG TAA AGC GGG } \\
\hline & TCA ACA TCT CTG TAT CCT GCG T & 50 & 0.6 \\
\hline \multicolumn{4}{|c|}{ T. denticola } \\
\hline & \multicolumn{3}{|l|}{ TAA TAC CGA ATG TGC TCA TTT ACA T } \\
\hline & TCA AAG AAG CAT TCC CTC TTC TTC TTA & 60 & 0.3 \\
\hline
\end{tabular}

$\mathrm{Kb}$ : kilobases.

Table 3

Percentage of positive samples and odds ratios (confidence interval-CI 95\%) for each test organism in subgingival plaque samples from periodontally healthy and periodontitis subjects

\begin{tabular}{|c|c|c|c|c|c|c|c|c|}
\hline \multirow[b]{2}{*}{ Microorganism } & \multicolumn{4}{|c|}{ Culture detection } & \multicolumn{4}{|c|}{ PCR detection } \\
\hline & $\begin{array}{l}\text { Healthy } \\
\text { subjects }\end{array}$ & $\begin{array}{c}\text { Periodontal } \\
\text { disease }\end{array}$ & $\begin{array}{c}\text { OR } \\
\text { (CI 95\%) }\end{array}$ & $\begin{array}{c}P \\
\text { Value }\end{array}$ & $\begin{array}{l}\text { Healthy } \\
\text { subjects }\end{array}$ & $\begin{array}{c}\text { Periodontal } \\
\text { disease }\end{array}$ & $\begin{array}{c}\text { OR } \\
\text { (CI 95\%) }\end{array}$ & $\begin{array}{c}\mathrm{P} \\
\text { Value }\end{array}$ \\
\hline A. actinomycetemcomitans & 48 & 80 & $1.93(1.32-2.8)$ & 0.00177 & 70 & 90 & $1.71(1.20-2.44)$ & 0.024 \\
\hline B. forsythus & 10 & 40 & $3.0(1.34-6.710)$ & 0.001 & 30 & 82 & $2.97(1.88-4.70)$ & 0.00047 \\
\hline P. gingivalis & 60 & 70 & $1.24(0.84-1.83)$ & 0.290 & 66 & 78 & $1.32(0.90-1.96)$ & 0.260 \\
\hline C. rectus & 46 & 60 & $1.32(0.89-1.96)$ & 0.220 & 48 & 80 & $1.93(1.32-2.80)$ & 0.0017 \\
\hline E. corrodens & 64 & 64 & $1.0(0.66-1.50)$ & 0.830 & 50 & 80 & $1.86(1.28-2.69)$ & 0.0033 \\
\hline P. intermedia & 50 & 74 & $1.63(1.12-2.39)$ & 0.023 & 64 & 84 & $1.60(1.11-2.31)$ & 0.040 \\
\hline F. nucleatum & 84 & 90 & $1.27(0.79-2.06)$ & 0.55 & 92 & 96 & $1.36(0.75-2.49)$ & 0.67 \\
\hline T. denticola & - & - & - & - & 32 & 60 & $1.81(1.16-2.83)$ & 0.000 \\
\hline
\end{tabular}

Comparison between PCR and culture. The percentage of identical results comparing PCR and culture (PCR-positive and culture-positive or PCR-negative and culture-negative) occurred from $93 \%$ for $F$. nucleatum to $66 \%$ for A. actinomycetemcomitans in healthy and periodontal subjects, respectively. The major discrepancy between PCR and culture (PCR-positive and culture-negative or PCR-negative and culture-positive) were several ranging from $55 \%$ for $A$. actinomycetemcomitans to $7.4 \%$ for F. nucleatum (Table 4).

\section{DISCUSSION}

The use of 16S rRNA gene-based PCR detection was able to identify unique regions suitable for PCR application. PCR was able to distinguish microorganisms with considerable phenotypic similarity such as $A$. actinomycetemcomitans and $H$. aphrophilus, species found in subgingival plaque. These organisms are inhabitants of periodontal pockets and are difficult to distinguish by conventional culture ${ }^{1}$. A series of PCR 


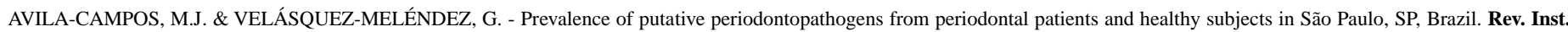
Med. trop. S. Paulo, 44(1):1-5, 2002.

Table 4

Microbial detection by culture and PCR in 50 gingival samples from healthy subjects and 50 periodontal disease patients

\begin{tabular}{|c|c|c|c|c|c|c|c|c|c|}
\hline \multirow{3}{*}{ Microorganism } & \multicolumn{4}{|c|}{ PCR (-) } & \multicolumn{4}{|c|}{$\operatorname{PCR}(+)$} & \multirow{3}{*}{ Identical results $\%$} \\
\hline & \multicolumn{2}{|c|}{ Culture (-) } & \multicolumn{2}{|c|}{ Culture (+) } & \multicolumn{2}{|c|}{ Culture (-) } & \multicolumn{2}{|c|}{ Culture (+) } & \\
\hline & $\mathrm{n}$ & $\%$ & $\mathrm{n}$ & $\%$ & $\mathrm{n}$ & $\%$ & $\mathrm{n}$ & $\%$ & \\
\hline A. actinomycetemcomitans & 11 & 55 & 9 & 45 & 25 & 31.3 & 55 & 68.8 & 66 \\
\hline B. forsythus & 43 & 97.7 & 1 & 2.3 & 32 & 57.1 & 24 & 42.9 & 67 \\
\hline P. gingivalis & 27 & 96.4 & 1 & 3.6 & 8 & 11.1 & 64 & 88.9 & 91 \\
\hline C. rectus & 34 & 94.4 & 2 & 5.6 & 13 & 20.3 & 51 & 79.7 & 85 \\
\hline E. corrodens & 21 & 60 & 14 & 40 & 15 & 23.1 & 50 & 76.9 & 71 \\
\hline P. intermedia & 26 & 100 & 0 & 0 & 12 & 16.2 & 62 & 83.8 & 88 \\
\hline F. nucleatum & 6 & 100 & 0 & 0 & 7 & 7.4 & 87 & 92.6 & 93 \\
\hline T. denticola & - & - & - & - & - & - & - & - & - \\
\hline
\end{tabular}

(+): positive; (-) : negative; n: number of samples

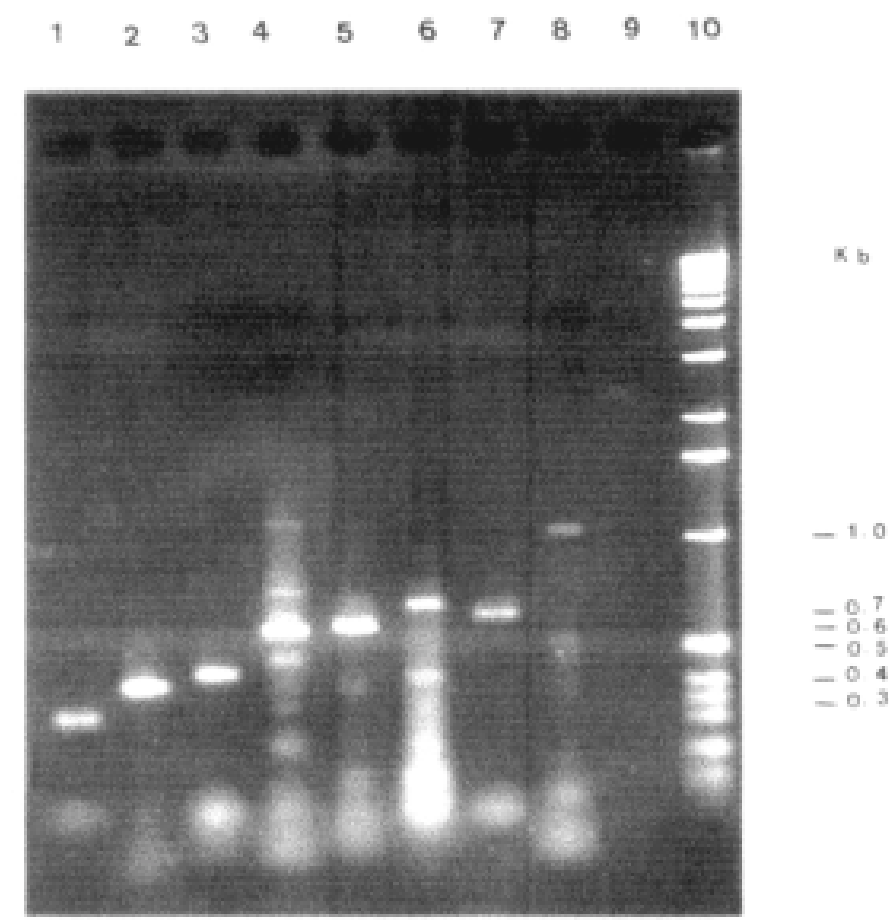

Fig. 1 - PCR products to different periodontopathogenic microorganisms using various primer pairs. Lane 1, T. denticola; lane 2, P. gingivalis; lane 3, A. actinomycetemcomitans; lane 4, $P$. intermedia; lane 5, C. rectus; lane 6, E. corrodens; lane 7, B. forsythus; lane 8, F. nucleatum; lane 9, negative control; lane 10, 1-Kb DNA ladder.

amplification products with different sizes ranging between 0.3 to $1 \mathrm{~Kb}$ for every used primer pairs were obtained. PCR analysis was used sucessfully to identify different periodontopathogens associated with human periodontitis such as A. actinomycetemcomitans, B. forsythus, $P$. gingivalis, $P$. intermedia, $C$. rectus, E. corrodens, $F$. nucleatum or $T$. denticola (Fig. 1). It was valuable for identification of bacterial species with high degree of phenotypic and genotypic similarity. For example, A. actinomycetemcomitans and $H$. aphrophilus, share many characteristics and are both found in subgingival microbiota. On the other hand, further studies should be done to demonstrate the value of 16S PCR for species-specific detection of A. actinomycetemcomitans in clinical samples (in VMGA III medium) from patients with periodontitis.

Studies have shown that hemoglobin or other compounds in subgingival specimens do not significantly inhibit the DNA amplification reaction ${ }^{2}$. The presence of dead bacteria within the sample may have increased the detection using the PCR methodology, but it is unlikely that dead cells remain in the subgingival biofilm for very long, being degraded and disposed of by the other bacteria ${ }^{4}$.

The prevalence of A. actinomycetemcomitans, B. forsythus, C. rectus, $E$. corrodens, $P$. intermedia and $T$. denticola was significantly higher by PCR detection $(p \leq 0.05)$. F. nucleatum was the most commonly detected species in both the healthy and periodontal subjects by either method of detection. Also, A. actinomycetemcomitans, $P$. gingivalis, $C$. rectus, E. corrodens and $P$. intermedia, were prevalent in both of subject groups, and it may suggest that these six organisms (including $F$. nucleatum) may be part of the oral indigenous microbiota. Also, these organisms may be considered endogenous pathogens that occasionally contribute to the development of periodontitis. Our data, also revealed a lower prevalence of $B$. forsythus and T. denticola in healthy subjects suggesting that these pathogens may be increased in periodontal infectious processes.

Higher odds ratios observed for these detected periodontal organisms might suggest a symbiotic relationship in periodontal pockets producing a destructive disease without interacting with each other. Although, a suitable therapeutic to obtain a bacterial elimination may be of great clinical benefits ${ }^{1}$. In addition, the use of specific primers represent an appropriate tool to identify or detect periodontopathogens from mixed bacterial populations.

\section{ACKNOWLEDGEMENTS}

The authors thank Dr. Leonard W. Mayer for his collaboration and critical review. This study was supported by grant from Fundação de Amparo à Pesquisa do Estado de São Paulo (FAPESP), SP, No. 98/ 15572-8, and Conselho Nacional de Desenvolvimento Científico e Tecnológico (CNPq) No. 301610/92-4, Brasilia, DF, Brazil. 


\section{RESUMO}

\section{Prevalência de periodontopatógenos em pacientes com doença periodontal e indivíduos sadios de São Paulo, SP, Brasil}

Cepas de A. actinomycetemcomitans, B. forsythus, $P$. gingivalis, $C$. rectus, $E$. corrodens, $P$. intermedia, $F$. nucleatum e $T$. denticola foram identificadas da placa subgengival de 50 pacientes com doença periodontal e 50 indivíduos sadios. Os produtos de PCR de cada espécie microbiana mostraram bandas específicas, favorecendo a identificação direta de bactérias periodontais de espécimes clínicos. Resultados negativos ou positivos idênticos entre PCR e a cultura ocorreram de $66 \%$ (A. actinomycetemcomitans) a $93 \%$ (F. nucleatum) das amostras. A detecção de A. actinomycetemcomitans, B. forsythus, C. rectus, E. corrodens, $P$. intermedia e $T$. denticola por PCR foi significativamente associada com a doença, mostrando valores altos de odds ratio (OR) para $B$. forsythus $(2,97,95 \%$ CI 1,88 - 4,70). Através da cultura foi observada a associação de $A$. actinomycetemcomitans, $B$. forsythus e $P$. intermedia com a periodontite, entretanto, $P$. gingivalis, $C$. rectus, $E$. corrodens e $F$. nucleatum não foram significativamente relacionados à doença.

\section{REFERENCES}

1. ASHIMOTO, A.; CHEN, C.; BAKKER, I. \& SLOTS, J. - Polymerase chain reaction detection of 8 putative periodontal pathogens in subgingival plaque of gingivitis and advanced periodontitis lesions. Oral Microbiol. Immunol., 11: 266-273, 1996.

2. AVILA-CAMPOS, M.J.; SACCHI, C.T.; WHITNEY, A.M.; STEIGERWALT, A.G. \& MAYER, L.W. - Arbitrary primed-polymerase chain reaction for identification and epidemiologic subtyping of oral isolates of Fusobacterium nucleatum. J. Periodont., 70: 1202-1208, 1999.

3. BOLSTAD, A.I. \& JENSEN, H.B. - Polymerase chain reaction-amplified nonradioactive probes for identification of Fusobacterium nucleatum. J. clin. Microbiol., 31: 528$532,1993$.
4. CHEN, C. \& SLOTS, J. - Microbiological tests for Actinobacillus actinomycetemcomitans and Porphyromonas gingivalis. Periodontology 2000, 20: 53-64, 1999.

5. EISENSTEIN, B.I. - New molecular techniques for microbial epidemiology and the diagnosis of infectious diseases. J. infect. Dis., 161: 595-602, 1990.

6. FURCHT, C.; ESCHRICH, K. \& MERTE, K. - Detection of Eikenella corrodens and Actinobacillus actinomycetemcomitans by use of the polymerase chain reaction (PCR) in vitro and in subgingival plaque. J. clin. Periodont., 23: 891-897, 1996.

7. MÉNARD, C.; BROUSSEAU, R. \& MOUTON, C. - Application of polymerase chain reaction with arbitrary primer (AP-PCR) to strain identification of Porphyromonas (Bacteroides) gingivalis. FEMS Microbiol. Lett., 95: 163-168, 1992.

8. MÖLLER, A.J.R. - Microbiological examination of root canals and periapical tissues of human teeth: methodological studies. Odont. T., 74 (suppl. 1): 1-380, 1966.

9. MOORE, W.E.C. - Microbiology of periodontal disease. J. Periodontal Res., 22: 335$341,1987$.

10. SLOTS, J. \& TING, M. - Actinobacillus actinomycetemcomitans and Porphyromonas gingivalis in human periodontal disease: occurrence and treatment. Periodontology 2000, 20: 82-121, 1999.

11. SLOTS, J.; ASHIMOTO, A.; FLYNN, M.J.; LI, G. \& CHEN, C. - Detection of putative periodontal pathogens in subgingival specimens by $16 \mathrm{~S}$ ribosomal DNA amplification with the polymerase chain reaction. Clin. infect. Dis., 20 (suppl. 2): S304-S307, 1995.

12. WATANABE, K. \& FROMMEL, T.O. - Porphyromonas gingivalis, Actinobacillus actinomycetemcomitans and Treponema denticola detection in oral plaque samples using the polymerase chain reaction. J. clin. Periodont., 23: 212-219, 1996.

13. ZAMBON, J.J.; SLOTS, J. \& GENCO, R.J. - Serology of oral Actinobacillus actinomycetemcomitans and serotype distribution in human periodontal disease. Infect. Immun., 41: 19-27, 1983.

Received: 06 September 2001

Accepted: 09 November 2001 